http://dx.doi.org/10.12775/szhf.2014.004

Karol Michalski

\title{
Fenomenologia na drodze myślowej Martina Heideggera
}

Pojęcie fenomenologii w XX wieku wiąże się z filozofią Edmunda Husserla (1859-1938). Fenomenologia nie jest początkiem drogi myślowej Martina Heideggera (1889-1976). Droga ta ma swój początek w teologii: („Nigdy bym nie dotarł do drogi myślenia, gdyby nie ta teologiczna przeszłość. A przeszłość pozostaje zawsze przyszłością." ${ }^{1}$ i w wczesnej fascynacji ontologią:

Z licznych wzmianek w czasopismach filozoficznych dowiedziałem się, że sposób myślenia Husserla ukształtowany został przez Franza Brentano. Jego dysertacja Von der mannigfachen Bedeutung des Seienden nach Aristoteles (1862; O różnych znaczeniach bytu wedle Arystotelesa) była wszak od 1907 roku moją pierwszą nieporadną i chwiejną próbą wniknięcia w filozofię. W dość nieokreślony sposób poruszyła mnie myśl: skoro o bycie mówi się w różnych znaczeniach, które z nich jest przewodnim znaczeniem podstawowym? Co to znaczy bycie? ${ }^{2}$

Fenomenologia nie jest odcinkiem drogi myślowej Heideggera, ale sposobem poruszania się na pewnym odcinku myślenia. Droga myślowa Heideg-

\footnotetext{
${ }^{1}$ M. Heidegger, $W$ drodze do języka, tłum. J. Mizera, Warszawa 2007, s. 85.

2 Tenże, Ku rzeczy myślenia, tłum. K. Michalski, J. Mizera, C. Wodziński, Warszawa 1999, s. 101 .
} 
gera prowadzi przez fenomenologię i fundamentalną ontologię do myślenia bycia $^{3}$.

Stosunek Heideggera do fenomenologii jest ambiwalentny: entuzjastyczny i zdystansowany. Były lata, kiedy intensywnie zajmował się problematyką fenomenologiczną i otwarcie mówił w swoich badaniach o metodzie fenomenologicznej. Potem przez dłuższe okresy milczał o fenomenologii, zastepując ją nawet pojęciem filozofii. W latach 50., patrząc wstecz na swoją drogę filozoficzną, pisze:

Tymczasem nie chodziło mi ani o jakiś kierunek fenomenologii, ani o coś nowego. Raczej przeciwnie, próbowałem bardziej źródłowo myśleć istotę fenomenologii, aby w ten sposób włączyć ją do filozofii zachodniej

Aby ugruntować istotę fenomenologii, sięga Heidegger aż do filozofii antycznej, przede wszystkim do Arystotelesa. Dokonuje reinterpretacji podstawowych pojęć fenomenologicznych. Fenomenologia toruje Heideggerowską drogę filozoficzną i otwiera metafizyczną przestrzeń myślenia. Jeszcze w 1973 roku prowadzi w swoim domu, w dzielnicy Zähringen, na przedmieściach Fryburga, seminarium z filozofii fenomenologicznej (Poszukiwanie dostępu do pytania o byciu u Husserla, Husserla ogląd kategorialny, Husserla wkład w historię metafizyki) ${ }^{5}$.

Z fenomenologią zetknął się Heidegger po raz pierwszy poprzez Logische Untersuchungen (1900/1901) Husserla.

Moje studia akademickie rozpoczęły się zimą 1909/1910 na Wydziale Teologicznym Uniwersytetu we Fryburgu. Teologia jako przedmiot główny pozostawiała jednak jeszcze dość miejsca na należącą zresztą do zakresu studiów filozofię. Tak więc od pierwszego semestru oba tomy Badań logicznych Husserla leżały na moim studenckim pulpicie w konwikcie teologicznym. Należały one do biblioteki uniwersyteckiej. Termin ich zwrotu mógł być zawsze bez trudu przedłużony. Praca ta budziła oczywiście niewielkie zainteresowanie wśród studentów. W jaki jednak sposób dostała się w obce jej otoczenie mojego pulpitu studenckiego ${ }^{6}$

${ }^{3}$ Por. tenże, Identität und Differenz, Gesamtausgabe, Ausgabe letzter Hand, Band 11., Herausgegeben von Fr.-W. von Herrmann, Frankfurt am Main 2006, s. 148-149.

${ }^{4}$ Tenże, $W$ drodze do języka, s. 84.

${ }^{5}$ Por. tenże, Seminare, Gesamtausgabe, Ausgabe letzter Hand, Band 15, Herausgegeben von

C. Ochwadt, Frankfurt am Main 2005, s. 372-400.

${ }^{6}$ Tenże, Ku rzeczy myślenia, s. 101. 
Z Husserlem spotkał się Heidegger w 1916 roku, kiedy ten przybył z Getyngi do Fryburga, jako następca Heinricha Rickerta, który objął katedrę filozofii po Windelbandzie w Heidelbergu. Dziełem Logische Untersuchungen, w którym rozwinął fenomenologię deskryptywną, ugruntował Husserl filozofię fenomenologiczną. Z kolei dziełem Ideen zu reinen Phänomenologie und phänomenologischen Philosophie (1913) usiłował Husserl ugruntować fenomenologię na podstawie transcendentalnej. Tym zamierzeniem ryzykował rozłam w ruchu fenomenologicznym. We Fryburgu zgromadził wokół siebie grono uzdolnionych uczniów, którzy mieli rozwijać jego idee filozofii fenomenologicznej. Przez dziesięć lat należał Heidegger do elity młodych fenomenologów, wybijając się na czoło tej formacji i ciesząc się wyjątkowym uznaniem i poparciem Husserla. Po przyjeździe Husserla do Fryburga Heidegger mógł się poświęcić systematycznym badaniom fenomenologicznym, przerywanym przygotowaniami do służby wojskowej i udziałem w działaniach militarnych (kolejno na stanowiskach strażniczym i pomiarów meteorologicznych).

W 1918 roku, dzięki wstawiennictwu Husserla, otrzymuje Heidegger stypendium, umożliwiające mu dalsze studiowanie. W 1919 roku, również na wniosek Husserla, dostaje Heidegger samodzielne stanowisko wykładowcze z wynagrodzeniem na Fakultecie Filozoficznym. Nieco później obejmuje nowo powstałe stanowisko asystenta.

Kiedy od 1919 nauczając-i-ucząc-się w pobliżu Husserla, wprawiałem się $\mathrm{w}$ fenomenologicznym widzeniu i zarazem wypróbowywałem na seminarium zmienione rozumienie Arystotelesa, moje zainteresowania znów skłaniały się ku Badaniom logicznym, przede wszystkim ku badaniu szóstemu z pierwszego wydania. Wypracowana tam różnica między naocznością zmysłową i kategorialną ujawiła mi się w swej doniosłości dla określenia „różnych znaczeń bytu””

W Logische Untersuchungen Heidegger nie spodziewał się znaleźć rozwinięcia ontologicznych wątków rozprawy Brentano. Potem odszukał w nich trop na drodze do myślenia bycia uobecniającego się w różnych sposobach bytowania. W tym czasie co tydzień regularnie czyta ze studentami Logische Untersuchungen, których sam Husserl nie oceniał już szczególnie wysoko, radykalizując swoją postawę transcendentalną. Tolerował jednak z pobłażliwością i wielkodusznością postępowanie badawcze Heideggera.

7 Tamże, s. 107. 
Heidegger właściwie nigdy nie był uczniem Husserla, chociaż nazywał go swoim nauczycielem, mistrzem i ojcowskim przyjacielem. Kiedy poznał go bliżej, miał już za sobą filozoficzną edukację szkolną (doktorat - 1913, habilitacja - 1915). Husserl ubolewał nad tym, że nie mógł go filozoficznie ukształtować: „ja przecież nie miałem niestety wpływu na jego filozoficzne wykształcenie, najwidoczniej miał on już tę swoistość (Eigenart), kiedy studiował moje pisma”. Tą „swoistością” było u Heideggera konsekwentne i radykalne postępowanie na drodze myślenia $\mathrm{w}$ pobliże, $\mathrm{w}$ sąsiedztwo bycia, któremu to postępowaniu kierunek wyznaczała fenomenologia.

Po zakończeniu pierwszej wojny światowej intensywnie zajmuje się problematyką fenomenologiczną. Od wiosny 1919 do semestru wiosennego 1922 regularnie uczestniczy w ćwiczeniach Hussserla. Od lata 1919 roku sam prowadzi ćwiczenia fenomenologiczne dla początkujących i zaawansowanych. Od jesieni 1920 roku, już wspólnie z Husserlem, oficjalnie prowadzi ćwiczenia $\mathrm{z}$ fenomenologii. W tym czasie podczas wykładów analizuje następujące tematy: podstawowe pytania fenomenologii, transcendentalna filozofia wartości a fenomenologia, wprowadzenie do fenomenologii, fenomenologia oglądu i wyrazu, problem filozoficznego kształtowania pojęcia, wprowdzenie do fenomenologii religii. Te badania fenomenologiczne przybliżają go coraz bardziej do własnych idei ontologicznych:

Tak oto znalazłem się na drodze pytania o bycie, oświecony przez nastawienie fenomenologiczne, ponownie i w inny sposób zaniepokojony pytaniami, które wywodziły się z Brentanowskiej dysertacji. Droga zapytywania była jednak dłuższa, niż przypuszczałem. Wymagała wielu postojów, dróg okrężnych i bezdroży. To, co wypróbowywały pierwsze wykłady fryburskie, a później marburskie, ukazuje drogę jedynie pośrednio?.

Mimo instrumentalnego traktowania fenomenologii przez Heideggera, Husserl nadal upatrywał w nim swojego następcę i kontynuatora, który miałby produktywnie rozwijać jego koncepcje fenomenologiczne na gruncie nauki o sztuce i nauk humanistycznych. Na obszarze matematyki i nauk przyrodniczych miał to robić Oskar Becker.

Ruch fenomenologiczny nie był właściwie nigdy żadną szkołą filozoficzną zaprzysiężoną na mistrza. Był raczej, jak podkreślał to Max Scheler, pewnego

${ }^{8}$ E. Husserl, Briefwechsel, Band 3, Herausgegeben von K. Schumann, Dordrecht-Boston-London 1993, s. 234.

${ }^{9}$ M. Heidegger, Ku rzeczy myślenia, s. 108-109. 
rodzaju wzajemną współpracą pomiędzy filozofami, którzy odnaleźli swoją własną drogę filozoficzną. Ruch ten działał na zasadzie wolnego stowarzyszenia, umożliwiającego uczestnikom wspólny dialog filozoficzny. Także Heidegger poruszał się już po własnej drodze myślowej, kiedy wszedł w bliższy kontakt z Husserlem. Jako asystent Husserla występował z własnej pozycji filozoficznej, krytycznej wobec fenomenologii. Wiele czasu musiało upłynąć, zanim Husserl zorientował się, że Heidegger poszedł zupełnie inną ścieżką niż literalnie pojmowana droga filozofii fenomenologicznej.

W 1923 roku Heidegger zostaje powołany do Marburga jako profesor zwyczajny na stanowisko profesora nadzwyczajnego. W Marburgu w latach 1923-1928 prowadzi serię wykładów, w których intensywnie zajmuje się fenomenologią: Einführung in die phänomenologische Forschung, Prolegomena zur Geschichte des Zeitbegriffs, Die Grundprobleme der Phänomenologie, Phänomenologische Interpretation von Kants Kritik der reinen Vernunft. W innych wykładach marburskich fenomenologię rozumie jako fundamentalny sposób rozważania problematyki filozoficznej. Pisze z entuzjazmem we wstępie do wykładów Platon: Sophistes (semester zimowy 1924/25):

Decydujące jest to, że fenomenologia dała ponownie możliwość do tego, by na polu filozofii naukowo stawiać pytania i dawać odpowiedzi. Czy rozwiąże ona wszystkie pytania filozofii, to się jeszcze nie rozstrzygnęło. Jeżeli dobrze rozumie ona siebie i epokę, to będzie się ona najpierw ograniczała do pracy nad tym, aby doprowadzić rzeczy, o których ma traktować, do spojrzenia na nie $\mathrm{i}$ ich rozumienia. Wprowadzenie do fenomenologii odbywa się nie przez to, że się czyta literaturę fenomenologiczną i zapamiętuje sobie to, co w niej stwierdzono. Nie znajomość poglądów jest wymagana. $W$ ten sposób fenomenologia byłaby od razu źle zrozumiana. Raczej konkretna praca nad rzeczami musi być drogą, na której można zdobyć zrozumienie fenomenologii. Nie chodzi o to, żeby odwoływać się do fenomenologicznych kierunków i dyskusji, ale o to, aby poprzez pracę przekładania mowy rzeczy, wejść w położenie widzenia fenomenologicznego. Jeśli zdobyło się rozumienie rzeczy, wtedy fenomenologia może zniknąc ${ }^{10}$.

Podczas pobytu w Marburgu, o ile tylko jest to możliwe, ucieka Heidgger na południe do Schwabii, do Hochschwarzwald, w okolice Fryburga, do górskiej chaty w Todtnauberg, gdzie pracuje nad swym opus magnum - Sein und

${ }_{10}$ Tenże, Platon: Sophistes, Gesamtausgabe, Ausgabe letzter Hand, Band 19, Herausgegeben von I. Schüßler, Frankfurt am Main 1992, s. 9-10. 
Zeit. W tym czasie znajdował się Heidegger pod naciskiem władz administracyjnych. Fakultet Filozoficzny Uniwersytetu w Marburgu zaproponował go wcześniej unico loco jako następcę Nicolaia Hartmanna w pierwszej katedrze filozofii. Oczekiwano od niego publikacji. Pewnego dnia podczas semestru zimowego 1925/26 zapytał go dziekan marburskiego fakultetu filozoficznego, czy dysponuje już odpowiednim manuskryptem do druku. Kiedy Heidegger powiedział, że tak, dziekan nalegał, że musi to być szybko wydrukowane. Tymczasem z Pruskiego Ministerstwa Nauki z Berlina przyszła wiadomość, że kandydatura Heideggera została cofnięta, ponieważ od dziesięciu lat nic nie opublikował. W wydawnictwie Max Niemeyer, dzięki pośrednictwu Husserla, wydrukowano pospiesznie pierwszych piętnaście arkuszy Sein und Zeit i za pośrednictwem władz fakultetu wysłano do Berlina. Po dłuższym czasie nadeszła odpowiedź z uwagą: "niewystarczające”. Dopiero po ukazaniu się całego dzieła Sein und Zeit decyzja ministerialna została odwołana. Ale wtedy Heidegger nie był już zainteresowany katedrą w Marburgu.

Z okazji urodzin 8 kwietnia 1926 roku Heidegger przekazuje Husserlowi części manuskryptu Sein und Zeit w rulonie udekorowanym kwiatami. Uczniowie Husserla i sam mistrz pomagają z zapałem przy korekcie manuskryptu dzieła. Jeszcze przed ukazaniem się Sein und Zeit Husserl powiadał, że Heidegger i on - to jest fenomenologia. We wrześniu tego samego roku Heidegger został zaproszony przez Husserla na osiem dni do Engadin w Alpy Szwajcarskie. W tamtych czasach filozofia żyła nie tylko na salach uniwersyteckich, w bibliotekach i gabinetach, lecz także w niekończących się rozmowach. W Marburgu Heidegger rozpoczynał wykłady z filozofii Arystotelesa o siódmej rano, co było, niesłychaną prowokacją wymierzoną w jego kolegę Hartmanna, prowadzącego w nocy dysputy ze studentami, którzy następnego dnia mieli być u Heideggera na zajęciach.

Wiosną 1927 roku, w ósmym tomie „Jahrbuch für Philosophie und phänomenologische Forschung" ukazują się dwie prace, w których Husserl upatrywał możliwość rozwinięcia filozofowania fenomenologicznego. Były to: Sein und Zeit Heideggera i Mathematische Existenz Oskara Beckera. W tamtych burzliwych czasach zwrócono uwagę jedynie na Sein und Zeit, uważane dzisiaj za źródło destrukcji tradycyjnej filozofii i początek filozofii egzystencji. W egzemplarzu podarowanym Husserlowi przez Heideggera, wpisał on słowa Lessinga: „Die größte Deutlichkeit war mir immer die größte Schönheit” („Największa wyrazistość była dla mnie zawsze największym pięknem”). Później Husserl, podczas dwumiesięcznego letniego urlopu nad jeziorem Lago di Como, zabrał się do lektury dzieła, umieszczając, swoim zwyczajem, krytycz- 
ne uwagi na marginesie. Notatki Husserla na tym legendarnym egzemplarzu Sein und Zeit stanowią świadectwo jego sprzeciwu wobec filozofii Heideggera $\mathrm{z}$ tego okresu ${ }^{11}$.

Heidegger dedykował Sein und Zeit Husserlowi z wdzięczności za otwarcie mu drogi do fenomenologicznego myślenia. Dedykacja ta poprzedzała jeszcze czwarte wydanie z 1935 roku; z następnego wydania została usunięta. $\mathrm{Na}$ ten temat Heidegger złożył następujące wyjaśnienie:

Wobec przewidywanych przez wydawcę kłopotów z drukiem lub nawet zakazu publikacji piątego wydania książki w 1941 roku, na wniosek i życzenie Niemeyera postanowiono $\mathrm{w}$ końcu pominąć $\mathrm{w}$ tym wydaniu dedykację pod postawionym przeze mnie warunkiem zachowania przypisu na stronie 38 , który właściwie uzasadnia dopiero dedykację i brzmi „Jeśli poniższe badanie przyczyniło się do posunięcia naprzód kwestii otwarcia «rzeczy samych», to autor zawdzięcza to przede wszystkim Edmundowi Husserlowi, który podczas studiów odbywanych przez autora we Fryburgu Bryzgowijskim zaznajomił go z najróżniejszymi obszarami badań fenomenologicznych, udostępniając mu swe niepublikowane badania i osobiście w niezrównany sposób nimi kierując"12.

Heidegger paradoksalnie potrzebował Husserlowskiej metody filozofowania do zakwestionowania jego dorobku myślowego. Sein und Zeit, w którym Heidegger posługuje się metodą fenomenologiczno-ontologiczno-hermeneutyczną, jest zmaganiem się i rozprawieniem z fenomenologią transcendentalną Husserla. Heidegger nigdy nie akceptował fenomenologii jako dziedziny filozofii, kierunku filozoficznego, szkoły filozoficznej. Widział zawsze $\mathrm{w}$ fenomenologii pewien sposób filozofowania. Bliski mu był sam program fenomenologii postulujący konsekwentne, bezkompromisowe, radykalne i produktywne poszukiwanie istoty i prawdy rzeczy.

W Sein und Zeit jest napisane, że musimy pojmować i rozumieć fenomenologię nie w jej rzeczywistości, tylko w jej możliwości. Właściwą maksymą fenomenologii nie jest „zasada wszech zasad”, lecz maksyma „do rzeczy samej”! Nawet jeśli samą tą maksymę rozważymy fenomenologicznie, to powstaje pytanie: Co jest rzeczą filozofii? Czy jest nią świadomość? Trzeba by zapytać: Na jakiej drodze mogę znaleźć odpowiedź na to pytanie? Czy mogę to pytanie rozstrzy-

${ }^{11}$ Por. E. Husserl, Randnotitzen Husserls zu Heideggers Sein und Zeit und Kant und das Problem der Metaphysik, „Husserl Studies“ 1994, nr 11, s. 3-63.

${ }^{12}$ M. Heidegger, $W$ drodze do języka, s. 247-348. 
gnąć wyłącznie z siebie samego, we własnej egologicznej intuicji, czy też do tego rozważania koniecznie przynależy nie tylko jakieś historyczne (historisch), ale dziejowe (geschichtlich) odniesienie do dziejów (Geschichte); ponieważ dzieje myślenia nie są tylko jakąś gmatwaniną różnych minionych poglądów, lecz zawierają one wymaganie wobec nas, aby to samo pytanie, pytanie o bycie bytującego (Sein des Seienden), stawiać ciągle na nowo. Stąd też wynika następne pytanie, które uznaję za fenomenologiczne: Jeżeli metafizyka przez całe swoje dzieje mówi o bycie bytującego w różnych odmianach idea, energeia, actualitas, monada, przedmiotowość, duch absolutny, wiedza absolutna, wola władzy, to skąd określa się istota bycia (das Wesen von Sein)? ${ }^{13}$.

Podstawowym sensem filozofii jest dla Heideggera metafizyka: nauka o tym, co jest istotą bytu, w jaki sposób byt bytuje i jak wyłożyć istotny sposób bytowania bytu. W dziejach metafizyki na różne sposoby usiłowano określić istotę, sposób bycia i wykładnię bytu. Filozofia fenomenologiczna może w istotny sposób wpłynąć na jakość myślenia metafizycznego. Dla Heideggera metafizyka ma być, tak jak fenomenologia, wiedzą pierwotną, źródłową i początkową. Zadaniem metafizyki jest radykalny „powrót do rzeczy samych”, czyli myślenia bytów w świetle bycia. Punktem wyjścia tej drogi jest faktyczna i dziejowa egzystencja, która nie dokonuje oglądu przedmiotów, lecz napotyka rozumiejąco siebie samą, inne byty i bycie. Metafizyką wszelkiej metafizyki jest w rozumieniu Heideggera myślenie bycia. Pytaniem wszelkich pytań jest pytanie o prawdę bycia. Czym jest to, co jest podstawą wszelkiego bytowania? Czym jest to, co jest podstawą wszelkich podstaw? Czym jest to, co jest punktem odniesienia dla myślenia, skoro nie może tym być ani to, co bytuje, ani też człowiek? To jeszcze jest metafizyka, powie w jakiś czas potem Heidegger o Sein und Zeit. Nie podjął już w dalszych badaniach problematyki ontologiczno-egzystencjalnej, ponieważ był owładnięty tajemnicą bycia. Całe jego późniejsze myślenie krąży natarczywie wokół pytania o bycie. Czy istnieje tylko pośrednia droga do bycia poprzez myślenie bytów, czyli metafizyczna? Czy występuje może bezpośrednia (meta-metafizyczna) droga do myślenia bycia? Wszystkie tematy, którymi się potem zajmuje: prawda, myślenie, Bóg, technika, sztuka, mowa, Grund, Kehre, Ereignis, Ek-sistenz,

\footnotetext{
${ }^{13}$ M. Heidegger, Zur Sache des Denkens, Gesamtausgabe, Ausgabe letzter Hand, Band 14, Herausgegeben von Fr.-W. von Herrmann, Frankfurt am Main 2007, s. 147 [wydanie polskie (Ku rzeczy myślenia) nie zawiera przekładu notatek z seminarium Zeit und Sein (pt. Über das Zeitverständnis in der Phänomenologie und im Denken der Seinsfrage), do których odwołuję się w tym oraz w kolejnych cytatach].
} 
Dichtung, nie są rozważane z pozycji fundamentalnej ontologii, lecz z pozycji myślenia bycia, dokonującego destrukcji logocentryzmu i antropocentryzmu metafizyki Zachodniej.

Heidegger uchodzi za znawcę fenomenologii. Nie zamierzał tak po prostu zluzować Husserla na pozycji lidera ruchu fenomenologicznego, chociaż już w czasach marburskich przewyższał go rozgłosem i siłą oddziaływania Chciał odkryć szansę filozofii fenomenologicznej dla metafizyki. Wśród filozofów współczesnych najbardziej produktywnie pokazał on siłę myślenia fenomenologicznego. Być może był przez to w większym stopniu fenomenologiem niż sam Husserl.

Kiedy Heidegger w kwietniu 1926 roku ofiarował Husserlowi na jego urodziny większą część manuskryptu Sein und Zeit, Husserl powiedział mu, że przeprowadził własne badania nad czasem i życzyłby sobie, żeby właśnie Heidegger zajął się ich zredagowaniem. Heidegger odpowiedział, że bardzo chętnie podejmie się tego zadania, ale dopiero po opublikowaniu własnego tekstu. „Moje pytanie o czas zostało określone przez pytanie o bycie (Seinsfrage). Ono idzie w kierunku, który dla badań Husserla o wewnętrznej świadomości czasu, pozostawał zawsze obcy"14. Vorlesungen zur Phänomenologie des inneren Zeitbewußtseins zostały zredagowane przez Heideggera i ukazały się z jego - rzeczowym i wyważonym, lecz zdystansowanym - wprowadzeniem w 1928 roku w dziewiątym tomie „Jahrbuch für Philosophie und phänomenologische Forschung".

Między październikiem 1927 a marcem 1928 roku Husserl pozyskał Heideggera do współpracy nad artykułem Phenomenology do czternastego wydania Encyclopedia Britannica. Zamierzał wykorzystać doświadczenie filozoficzne Heideggera w określeniu pojęcia „fenomenologii”. Wspólne redagowanie tekstu doprowadziło między nimi do napięć i kontrowersji. Centralny punkt sporu był natury egologicznej. Heidegger nie godził się na rozdzielenie między ja transcendentalnym a ja faktycznym, czyli egzystującym bytem ludzkim (Dasein).

Dla Heideggera egzystowanie bytu ludzkiego jest nieredukowalne. Według Husserla z kolei transcendentalne ego różni się radykalnie od naturalnego ego, które podlega redukcji transcendentalnej. Obydwaj kurczowo trzymają się swoich racji i pozostają na niezmiennych pozycjach. Dnia 8 grudnia 1927 roku pisze Husserl do Heideggera: „Ponowne opracowanie londyńskiego artykułu, bardzo pieczołowicie przemyślane i uporządkowane, wypadło

${ }^{14}$ Tamże, s. 148. 
pięknie, ale całkiem inaczej, niż Pan by przypuszczał, chociaż istota pozostała zachowana" 15 .

Mimo różnic ciągle jeszcze widzi Husserl w Heideggerze swojego następcę i pragnie mu powierzyć dalsze losy fenomenologii. Wypowiadając się w 1928 roku na temat obsadzenia po nim katedry, zalicza Heideggera do "najbardziej znaczących filozoficznych nauczycieli naszych czasów”" W tym samym roku informuje go w Marburgu, że stoi primo et unico loco na liście kandydatów na objęcie po nim stanowiska we Fryburgu. W 1928 roku Heidegger przyjeżdża do Fryburga i obejmuje po Husserlu pierwszą katedrę filozofii. W dwa miesiące później jego stosunki z Husserlem ulegają znacznemu rozluźnieniu i ochłodzeniu. Zostają praktycznie zerwane. Pisze Heidegger w liście do Jaspersa:

Husserl całkiem stracił styl - jeśli kiedykolwiek go miał - co w ostatnim czasie stało się dla mnie bardziej problematyczne - waha się na wszystkie strony i głosi banały, że aż litość bierze. Żyje misją „, fundatora fenomenologii”, nikt nie wie, co to jest - kto był tu przez semestr, wie, co się dzieje - zaczyna się domyślać, że nikt już za nim nie idzie - sądzi naturalnie, że to zbyt trudne - oczywiście, „matematyki tego, co etyczne” (ostatnia nowość!) nie rozumie nikt ${ }^{17}$.

Dnia 8 kwietnia 1929 roku Husserl uroczyście obchodzi na uniwersytecie swoje siedemdziesiąte urodziny. $\mathrm{Z}$ tej okazji wręczono mu jubileuszowy tom prac uczniów, poprzedzony przedmową Heideggera, w której pisze on: „I także są te prace, które Panu przekazujemy, tylko potwierdzeniem tego, ze chcieliśmy pójść za Pana przewodnictwem, ale nie dowodem na to, że to postępowanie za nim się udało" ${ }^{18}$. Typowe dla Heideggera ostrożne i wieloznaczne stwierdzenie. Nie wiadomo, dlaczego próba pójścia za Husserlem miałaby zakończyć się niepowodzeniem. Dlatego, że uczniowie nie dorośli do poziomu mistrza i nie nadążali w postepowaniu za nim? Albo że nauka mistrza była nie do utrzymania i kontynuowania i dlatego poszli swoimi drogami?

\footnotetext{
${ }^{15}$ E. Husserl, Briefwechsel, IV, s. 149.

${ }_{16}$ Tenże, Briefwechsel, VIII, s. 195.

${ }^{17}$ M. Heidegger, K. Jaspers, Korespondencja 1920-1963, tłum. C. Wodziński, M. Łukasiewicz, J. M. Spychała, Toruń 2000, s. 34-35.

${ }^{18} \mathrm{M}$. Heidegger, Reden und andere Zeugnisse eines Lebensweges, Gesamtausgabe, Ausgabe letzter Hand, Band 16, Herausgegeben von H. Heidegger, Frankfurt am Main 2000, s. 58.
} 
Jeszcze w 1929 roku zwraca się Husserl do Heideggera przez „lieber Freund”, a Heidegger do Husserla przez „väterlicher Freund”, potem już tylko zwracają się do siebie, jeżeli muszą, przez „Herr Kollege”. Kontakt zostaje całkowicie zerwany.

Dnia 27 kwietnia 1938 roku Edmund Husserl umiera, a 29 kwietnia zostaje pogrzebany. Heidegger nie bierze udziału w pogrzebie. Pisze 6 marca 1950 roku w liście na dziewięćdziesiąte urodziny Malviny Husserl:

W tym dniu proszę Panią o wybaczenie mi, z mądrej dobroci swego serca, tej ludzkiej słabości, której padłem ofiarą, kiedy mąż Pani od nas odszedł. Poza tym jednym razem, gdy zawiodłem, nigdy jednak w moim nastawieniu nie było nawet cienia jakiejś obcości czy zgoła wrogości. Świadectwem tego może być to, że w tych tak złych latach i nad wyraz bolesnych dla Pani i bliskich, nigdy dzieła Husserla nie zostały usunięte $\mathrm{z}$ seminarium o nim, tak jak to gdzie indziej miało miejsce ${ }^{19}$.

Powody załamania się znajomości z Husserlem nie były w żadnym wypadku natury politycznej. Okoliczności historyczne, w jakich przyszło im obydwu żyć, nie są tego żadnym dowodem. Niestety, po wojnie, nawet w środowiskach filozoficznych, usiłowano właśnie w tamtych tragicznych czasach upatrywać źródła zerwania kontaktu między tymi dwiema osobowościami filozoficznymi. Nie wystarczyły filozoficzne i ludzkie powody dla wyjaśnienia zerwania tej przyjaźni i współpracy. Heidegger był później wielokrotnie konfrontowany z politycznymi przyczynami zerwania z Husserlem:

Nigdy nie „wyparłem” ani bezwzględnie, ani w jakikolwiek inny sposób, mojego żydowskiego nauczyciela Husserla, którego byłem następcą na katedrze fryburskiej od 1928 roku. Raczej, kiedy później nakazano usunięcie wszystkich dzieł autorów żydowskich, to rozkazu tego, na prowadzonym przeze mnie seminarium, nie tylko nie wykonałem, ale ustawicznie i z naciskiem publicznie zalecałem studium dzieł Husserla, co może być w każdym czasie potwierdzone przez świadków ${ }^{20}$.

Heidegger do końca próbował pojednać się z fenomenologią. Do końca niepokoiły go losy fenomenologii:

\footnotetext{
19 Tamże, s. 443.

${ }^{20}$ M. Heidegger, Reden und andere Zeugnisse eines Lebensweges, s. 459.
} 
A dziś? Wydaje się, że czas filozofii fenomenologicznej przeminął. Posiada ona wartość jako coś minionego, co już tylko w sensie historycznym figuruje obok innych kierunków filozoficznych. Swoistość fenomenologii nie polega jednak na tym, że jest ona jakimś kierunkiem. Jest ona zmieniającą się w czasie i tylko dzięki temu otwartą możliwością myślenia, możliwością sprostania temu, co dane zostało do myślenia. Jeśli fenomenologia zostanie tak zrozumiana i potraktowana, będzie mogła zniknąć jako hasło na korzyść rzeczy myślenia, jawność pozostaje tajemnicą ${ }^{21}$.

Heidegger zawsze twierdził, że filozofii najlepiej można się nauczyć w rozmowie. Prowadził nieustannie rozmowę z filozoficzną tradycją i współczesnością. Prawie wszystkie jego dzieła pierwotnie istniały jako wykłady, seminaria, ćwiczenia. Do filozofowania potrzebował zawsze rzeczywistego albo potencjalnego rozmówcy, chociaż to, co pisze jest polemiczne, ale nie dyskusyjne. Przez cały czas prowadził dialog ze swoimi opublikowanymi już tekstami i konsekwentnie je poprawiał. To nie były zwykłe korekty dla kolejnych wydań, tylko ulepszenia wynikające $\mathrm{z}$ rozmowy, prowadzącej do nowego widzenia problemu. Heidegger mówił, że fenomenologii nie można się nauczyć poprzez czytanie książek. Myślenie fenomenologiczne żyje w rozmowie. Taką właśnie rozmowę prowadził z Husserlem i fenomenologią. Nigdy nie mógł się pogodzić z tym, że się ona zakończyła: „I to właśnie jest tragiczne, że ta rozmowa została przerwana"22.

\section{Bibliografia}

Heidegger M., Sein und Zeit, Gesamtausgabe, Ausgabe letzter Hand, Band 2., Herausgegeben von Fr.-W. von Herrmann, Frankfurt am Main 1977.

Heidegger M., Wegmarken, Gesamtausgabe, Ausgabe letzter Hand, Band 9., Herausgegeben von Fr.-W. von Herrmann, Frankfurt am Main 2004.

Heidegger M., Unterwegs zur Sprache, Gesamtausgabe, Ausgabe letzter Hand, Band 12., Herausgegeben von Fr.-W. von Herrmann, Frankfurt am Main 1985.

Heidegger M., Zur Sache des Denkens, Gesamtausgabe, Ausgabe letzter Hand, Band 14., Herausgegeben von Fr.-W. von Herrmann, Frankfurt am Main 2007.

Heidegger M., Seminare, Gesamtausgabe, Ausgabe letzter Hand, Band 15., Herausgegeben von C. Ochwadt, Frankfurt am Main 2005.

${ }^{21}$ Tenże, Ku rzeczy myślenia, s. 111.

${ }^{22}$ Tenże, Zur Sache des Denkens, s. 149. 
Heidegger M., Reden und andere Zeugnisse eines Lebensweges, Gesamtausgabe, Ausgabe letzter Hand, Band 16., Herausgegeben von H. Heidegger, Frankfurt am Main 2000.

Heidegger M., Einführung in die Phänomenologische Forschung, Gesamtausgabe, Ausgabe letzter Hand, Band 17., Herausgegeben von Fr.-W. von Herrmann, Frankfurt am Main 2006.

Heidegger M., Platon: Sophistes, Gesamtausgabe, Ausgabe letzter Hand, Band 19., Herausgegeben von I. Schüßler, Frankfurt am Main 1992.

Heidegger M., Prolegomena zur Geschichte des Zeitbegriffs, Gesamtausgabe, Ausgabe letzter Hand, Band 20., Herausgegeben von P. Jaeger, Frankfurt am Main, 1994.

Heidegger M., Die Grundprobleme der Phänomenologie, Gesamtausgabe. Ausgabe letzter Hand, Band 24., Herausgegeben von. Fr.-W. von Herrmann, Frankfurt am Main 1997.

Heidegger M., Phänomenologische Interpretation von Kants Kritik der reinen Vernunft, Gesamtausgabe, Ausgabe letzter Hand, Band 25., Herausgegeben von. I. Görland, Frankfurt am Main 1995.

Heidegger M., Zur Bestimmung der Philosophie, Gesamtausgabe, Ausgabe letzter Hand, Band 56/57., Herausgegeben von B. Heimbüchel, Frankfurt am Main 1999.

Heidegger M., Grundprobleme der Phänomenologie, Gesamtausgabe, Ausgabe letzter Hand, Band 58., Herausgegeben von H.-H. Gander, Frankfurt am Main 1992.

Heidegger M., Phänomenologie der Anschauung und des Ausdrucks. Theorie der philosophischen Begriffsbildung, Gesamtausgabe, Ausgabe letzter Hand, Band 59., Herausgegeben von C. Strube, Frankfurt am Main 1993.

Heidegger M., Phänomenologie des religiösen Lebens, Gesamtausgabe, Ausgabe letzter Hand, Band 60 Herausgegeben von M. Jung, Th. Regehly, C. Strube, Frankfurt am Main 2011.

Heidegger M., Phänomenologische Interpretation zu Aristoteles. Einführung in die phänomenologische Forschung, Gesamtausgabe, Ausgabe letzter Hand, Band 61., Herausgegeben von W. Bröcker und K. Bröcker Oltmanns, Frankfurt am Main 1994.

Heidegger M., Phänomenologische Interpretation ausgewählter Abhandlungen des Aristoteles zu Ontologie und Logik, Gesamtausgabe, Ausgabe letzter Hand, Band 62., Herausgegeben von G. Neumann, Frankfurt am Main 2005. 


\section{Abstract \\ Phenomenology on the Path of Thinking of Martin Heidegger}

Phenomenology in the 20th century is connected with the philosophy of Edmund Husserl. The starting point of his philosophy is the assumption of correlation of consciousness and the world. The basic concept of intentionality of consciousness indicates that consciousness is always consciousness of something. So every Being of beings is only insofar, as it is based on experiencing, perceptive, thinking consciousness. Accordingly, the world is a correlate of consciousness.

Phenomenology is not the starting point and not the source of the thinking of Martin Heidegger. The philosophical thought of Heidegger has its roots in theology and in his early fascination for the ontology. The path of thinking of Heidegger leads through the phenomenology and through the fundamental ontology into the thinking of Being.

In his "Logical Investigations" Husserl laid the foundations for the phenomenological philosophy. Heidegger was always impressed by this work, but he could not understand and accept the equalization of phenomenology with transcendental philosophy. In phenomenology, especially in the principle "to the things themselves", Heidegger saw an excellent possibility for philosophy and for metaphysical thinking.

For ten years Heidegger was the leader among the young phenomenologists in Freiburg, and his major role was acknowledged by Husserl. Later, their ways of thinking diverged.

Heidegger dealt with the phenomenology throughout all his life. With his main work "Being and Time” he replaced Husserl as the leading figure of the phenomenological philosophy. Heidegger criticizes Husserl, that he has not drawn the ontological conclusions from the phenomenology. He always regretted that they misunderstood each other and at the end their contact was broken off.

Key words: Husserl, Heidegger, phenomenology 